\title{
Expression of TAAs in glioblastoma and expansion of anti-TAA -reactive T cells
}

\author{
Ernest Dodoo ${ }^{1}$, Liu zhenjiang², Bartek Jiri ${ }^{2}$, Oscar Persson², Qingda Meng ${ }^{2}$, Thomas Poiret ${ }^{2}$, Lalit Rane², \\ Christopher Illies ${ }^{2}$, Julia Karbach³ ${ }^{3}$ Elke Jäger ${ }^{3}$, Markus Maeurer ${ }^{2 *}$ \\ From Society for Immunotherapy of Cancer 29th Annual Meeting \\ National Harbor, MD, USA. 6-9 November 2014
}

\section{Purpose}

Active cellular therapy (ACT) using ex-vivo expanded $T$ cells from patients with cancer, obtained by apheresis, can represent a viable source for anti-cancer directed cellular therapy. TAAs expressed in glioblastoma may represent attractive targets for i) CARS, ii) transgenic $\mathrm{T}$ cells targeting nominal tumor antigens (e.g. NY-ESO-1) or iii) $\mathrm{T}$ cells enriched for TAA after ex vivo expansion.

\section{Methods}

Fresh blood samples were obtained from 50 patients with tumors of the central nervous system and tested for antiTAA reactivity. T cells were expanded without cytokines, with IL-2 and IL-7, or with IL-2, IL-15 and IL-21 and tested for CD4/8 expansion by flow cytometry and for IFN-gamma production by ELISA. PBMCs were expanded using IL-2/15/21 and peptides (15mers) covering TAAs (surviving or NY-ESO-1). The T cell phenotype (CD3, CD4, CD8, CD45RA and CCR7) was determined by flow cytometry and TAA-reactive $\mathrm{T}$ cells were identified by intracellular cytokine staining (IL-2, TNF, IFN and IL-17). TAA-specific IgG in serum was detected by a quantitative ELISA in patients with glioblastoma and in age- and sexmatched healthy donors. FGFRvIII was determined by RT-PCR and protein expression of survivin and NY-ESO-1 was evaluated by immunohistochemistry and graded using a scale from $1+$ to $4+$ along with pattern analysis of TAA expression.

\section{Results}

We could detect IFN-gamma responses in $25 \%$ blood samples for NY-ESO-1 and 30\% for survivin and antigen-specific CD8 / CD4+ T cell proliferation. Cellular responses could be augmented by adding cytokines, i.e. IL- 2 and IL-7 favored CD4+ T cell proliferation, IL-2, IL-15 and IL-21 favored CD8+ T cell proliferation. TAAs-reactive $T$ cells could be successfully expanded ex vivo and exhibited TAA-specific production of IFNgamma and TNFalpha and a CD8+CD45RA-CCR7+ phenotype. 38/50 specimens expressed NY-ESO-1, yet only 3/50 showed a strong, universal (4+) NY-ESO-1 protein expression pattern, 12/50 cancer lesions exhibited a strong (4+) staining for survivin defined by immunohistochemistry. $25 \%$ of glioblastoma tested positive for the FGFRvIII.

\section{Conclusion}

A TAA-specific WBA (whole blood assay) can be used to gauge the potential for expansion of TAA-reactive T cells in peripheral blood from patients with glioblastoma. TAAreactive $\mathrm{T}$ cells can be successfully expanded from patients with glioblastoma in IL-2, IL-15 and IL-21, they exhibit a central memory phenotype and produce a Th1 cytokine cytokine pattern. NY-ESO-1 expression in glioblastoma represents a viable target for anti-NY-ESO-1 directed $\mathrm{T}$ cells.

\section{Consent}

Written informed consent was obtained from the patient for publication of this abstract and any accompanying images. A copy of the written consent is available for review by the Editor of this journal.

\footnotetext{
Authors' details

${ }^{1}$ Dept. of Neurosurgery, Karolinska University Hospital, Stockholm, Sweden. ${ }^{2}$ Karolinska Insitutet, Stockholm, Sweden. ${ }^{3}$ Krankenhaus Nordwest, Frankfurt/ M., Germany.
}

${ }^{2}$ Karolinska Insitutet, Stockholm, Sweden

Full list of author information is available at the end of the article 
doi:10.1186/2051-1426-2-S3-P24

Cite this article as: Dodoo et al: Expression of TAAs in glioblastoma

and expansion of anti-TAA -reactive T cells. Journal for ImmunoTherapy of Cancer 2014 2(Suppl 3):P24.

Submit your next manuscript to BioMed Central and take full advantage of:

- Convenient online submission

- Thorough peer review

- No space constraints or color figure charges

- Immediate publication on acceptance

- Inclusion in PubMed, CAS, Scopus and Google Scholar

- Research which is freely available for redistribution 